\title{
Optimization and valorization of recycled fiber in non-woven fabric
}

\section{REZUMAT - ABSTRACT}

\section{Optimizarea și valorificarea fibrelor reciclate din nețesute}

\begin{abstract}
Gama și volumul produselor textile utilizate zilnic cresc exponențial în întreaga lume, atât în țările dezvoltate, cât și în cele în curs de dezvoltare. Prin urmare, problemele legate de gestionarea și valorificarea deșeurilor devin o provocare care necesită studii economice și tehnice aprofundate. În acest context, ne-am propus în această lucrare să prezentăm valoarea adăugată a două tipuri de deșeuri textile ale firelor și confecțiilor textile colectate de la producătorii de denim albastru. O evaluare a calității fibrelor regenerate prezintă proprietăți fizice și mecanice satisfăcătoare care le permit să fie utilizate pentru producerea materialelor textile nețesute. S-a investigat un set de proprietăți, iar rezultatele au arătat că structurile nețesute pot fi considerate o alternativă bună pentru exploatarea firelor și fibrelor de țesături reciclate.
\end{abstract}

Cuvinte-cheie: reciclare, fibră de bumbac, nețesut, industria textilă

\section{Optimization and valorization of recycled fiber in non-woven fabric}

The range and volume of textile products used every day is growing exponentiallythroughout the world, in both developed and developing countries. Therefore, the issues of waste Management and valorization become a challenge that requires depth economic and technical studies. In this setting, we aimed in this paper to give an added value of two kinds of textile wastes: yarns and textiles garments wastes collected from Blue denim manufacturer. A quality assessment of the reclaimed fibers shows satisfying physical and mechanical properties that allow them to be used to produce nonwoven textiles materials. A set of properties are investigated and results revealed that nonwoven structures can be considered as a good alternative for yarn and woven recycled fibers exploitation.

Keywords: recycling, cotton fiber, nonwoven, textile industry

\section{INTRODUCTION}

Several challenges related to environmental protection and economic benefitsmake recycling a preferred option for solid waste management. Therefore, recycling and reuse of industrial wastes became of great interest either by developed and developing countries [1-3].

The textile industry is characterized by many disposable products that create multiple environmental issues over its entire life cycle. Textile recycling is the method of reusing or reprocessing used clothing, fibrous material and clothing scraps from the manufacturing process. Clothing textile waste can be recycled and re-fiberized [4-5]. Youjiang Young presented an overview on textile waste recycling, focusing on the case of carpet [6]. This study contained a general assessment of fibrous waste, sources and material properties. A. Bartl et al. presented the state-of-the art in recycling fibers and the available technologies for textiles, carpets, composites and end-of life vehicles [7]. They demonstrate that fibers recycled from waste can be converted to a valuable raw material if processed properly. The quantitative and qualitative assessment of textile fiber waste is often linked with waste management and valorization. HALIMI et al. evaluated the waste percentage and the good fiber fraction for two cleaning machines and a card before the weaving step [8-10]. After this, the quality of recovered fibers was reviewed and confronted to other virgin material. These fibers can be blended in a good proportion without noticeable changes in final product quality. In addition, many studies have demonstrated that the reclaimed fibers can be reused and inserted with different proportion in different products with higher added value. Recently, nonwoven and fiber reinforced composites got considerable attention in numerous applications that can support the use of these recycled fiber.

Bechir Wannassi et al. worked to give an added value to cotton wastes by producing a new low cost yarn based on recycled yarn fibers [11]. Hence he investigated the effect of the raw material and the recycling process on the final quality of reclaimed fibers.

Finally, DoE method was used to find the optimum conditions for recycling process [12-13]. Related studies are achieved in order to develop new or alternative materials that aim to attain fuel efficiency, cost effectiveness, increased safety, and always with a target on capability to recycle or biodegrade [14].

In addition to a set of other investigated uses of reclaimed fibers on composites materials [15-17], Natascha M. van et al., after a life cycle assessment and eco-design of smart textiles, have demonstrated the importance of material selection through e-textile product redesign [18]. Results suggest several priority areas for environmental improvement of fibers [19]. 
In this study, we are interested inexploiting at the same time two kinds of wastes: yarns and fabric wastes collected from Blue denim manufacturers. The quality of recycled fibers is assessed then used to make a dry nonwoven. As a second part, the mechanical characteristics of these nonwovens were optimized to orientate their exploitation.

\section{MATERIALS AND METHODS}

Fibre recycling and characteristics

\section{Waste characteristics}

Yarn wastes used in this work are collected at the end of an Open-end process.Fabricwastes were collected from the end of the weaving process of Society of Textile Industries (SITEX). All tests in this study are conducted in the laboratory of SITEX Company while respecting ISO 139 standard. This standard describes the conditions of ambient that are $20 \pm 2{ }^{\circ} \mathrm{C}$ and $65 \%$ $\pm 4 \%$ air relative humidity. $24 \mathrm{~h}$ of conditioning of the materialis carried out before each test.

\section{Wastes recycling process}

The two kinds of wastes cannot be exploited in their current state and form. Then, restoringtheir initial state and transforming them to frayed fibers opens the door to several exploitation possibilities. For that, a mechanical process was adopted. Firstly, the yarn and woven waste was cut into small pieces with a length between $5 \mathrm{~cm}$ and $10 \mathrm{~cm}$. The second step was to use a fraying machine to transform this waste into fibers. At that level, we aimed to use frayed fiber in producing non-woven with satisfactory characteristic to be used in automotive, home building, furniture, mattress, home furnishings, apparel and other industries. For different reasons related to fibers properties and finished products, needle-punching technology is used to make non-woven. The overall process followed for fraying and non-woven manufacturing is presented in the flowchart of figure 1.

\section{Recycled fibers characteristics}

In addition to the manufacturing process and a set of other technical constraints, the use of the recycled fiber is mainly related to their quality and characteristics. For this reason, Advanced Fiber Information System (AFIS) and High volume instrument (HVI) are used to characterize the two kinds of recycled fibers.

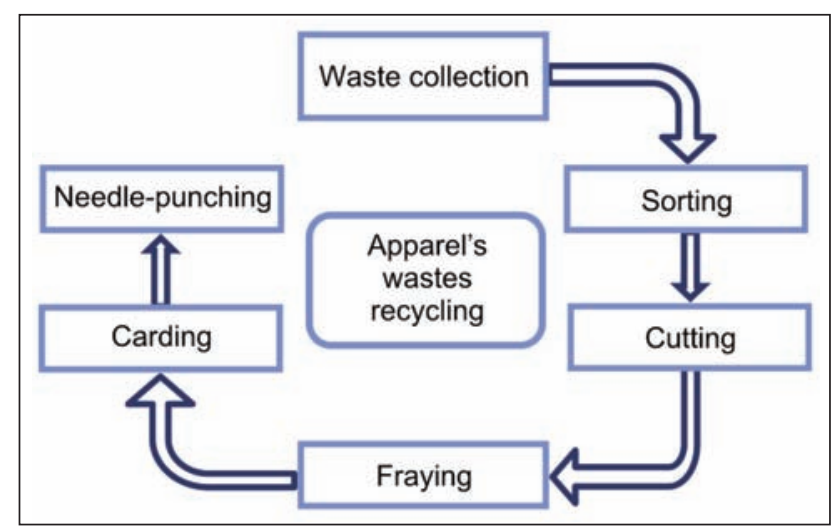

Fig. 1. Wastes recycling process

The main measurements include: the mean length, the length upper percentiles, the length $\mathrm{CV} \%$, and the Short Fiber Content, micronaire, length uniformity, strength, color, trash, maturity... etc.

\section{Preparation of needle-punched nonwoven fabric} and characteristics

Preparation of needle-punched nonwoven fabric The preparation of needle-punching nonwoven fabric has gone through four stages. It started by the raw material opening by the machine openers. In this first stage, the cleaning and blending seem to be crucial in order to supply regularly the carding machine. Secondly, blended fibers were carded with cotton carding machine in order to remove dirt particles, fiber alignment and web formation. During the next stage, the non-woven consolidation is performed by Needle-punching machine. This method consists of mechanically interlocking fibers by repeatedly punching through the fiber web with an array of barbed needles (figure 2, a). Typically, needling is used to consolidate a fibrous structure, to densify it and control the porosity (figure 2,b).

\section{Non-woven testing and evaluation}

All tests and nonwoven characterization were conducted in a conditioned laboratory $(65 \% \mathrm{RH}$ and $20^{\circ} \mathrm{C}$ ) while respecting ISO standards and recommended methods. Nonwoven samples were randomly cut $\left(100 \mathrm{~cm}^{2}\right)$ and before the determination of weight and thickness. The measurement was repeated 10 times for each test. The mechanical properties
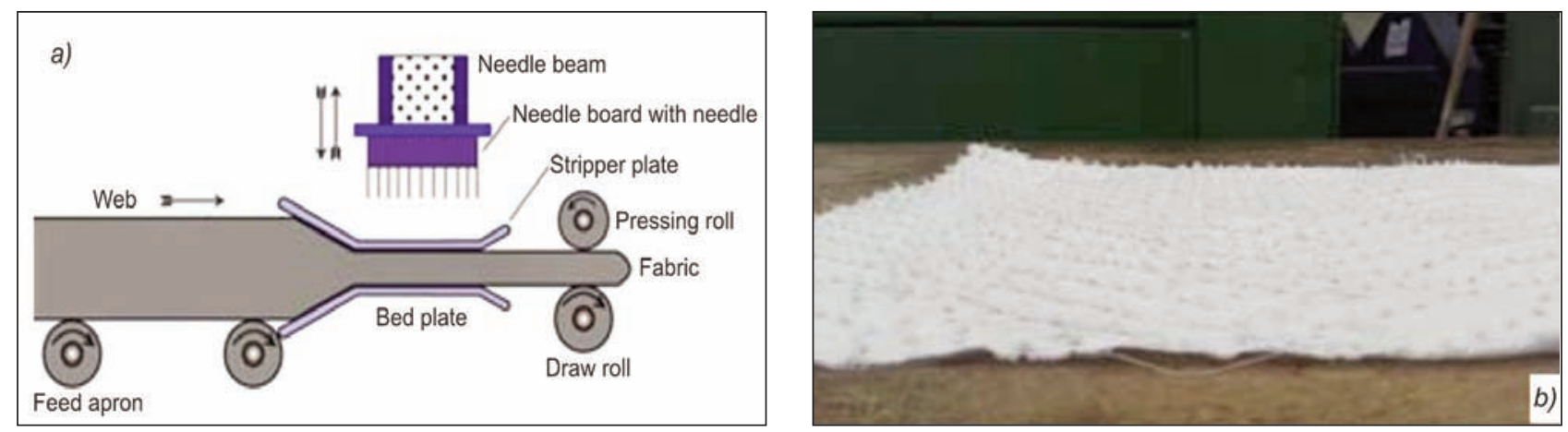

Fig. 2. (a) Needle punching principles and (b) Non-woven sample 
including breaking strength and elongation were determined using ISO 13934-1(1999) standard.

\section{DESIGN OF EXPERIMENTS}

The overall properties of non-woven produced from frayed fibers are mainly related toraw material properties and the needle punching process. A preliminary and literature study consultation show that the factors: fiber type (FT, YRF: fibers from frayed yarn; WRF: fibers from frayed fabric) needle punching passage (NPN) and layer number (LN), were influential on the quality of nonwoven. Table 1 show the levels of each factor considered in DoE. Therefore, L09 orthogonal array (table 2) was selected for the experimentation and each experiment was performed three times and the average in each experiment was considered as the response variable.

Table 1

\begin{tabular}{|c|c|c|c|c|}
\hline \multirow{2}{*}{ Level } & \multicolumn{2}{|c|}{$\begin{array}{c}\text { Fiber type } \\
\text { (FT\%) }\end{array}$} & $\begin{array}{c}\text { Needle punching } \\
\text { passage number }\end{array}$ & $\begin{array}{c}\text { Layer } \\
\text { number }\end{array}$ \\
\cline { 2 - 5 } & YRF & WRF & NPN & LN \\
\hline $\mathbf{1}$ & 75 & 25 & 1 & 2 \\
\hline $\mathbf{2}$ & 50 & 50 & 2 & 4 \\
\hline 3 & 25 & 75 & 3 & 8 \\
\hline
\end{tabular}

Table 2

\begin{tabular}{|c|c|c|c|c|}
\hline \multirow{2}{*}{ Sample } & \multicolumn{2}{|c|}{ FT } & \multirow{2}{*}{ NPN } & LN \\
\cline { 2 - 3 } \cline { 5 - 5 } & YRF & WRF & & $\mathbf{n}$ \\
\hline $\mathbf{1}$ & 25 & 75 & 2 & 1 \\
\hline $\mathbf{2}$ & 25 & 75 & 3 & 2 \\
\hline $\mathbf{3}$ & 25 & 75 & 4 & 3 \\
\hline $\mathbf{4}$ & 50 & 50 & 2 & 2 \\
\hline $\mathbf{5}$ & 50 & 50 & 3 & 3 \\
\hline $\mathbf{6}$ & 50 & 50 & 4 & 1 \\
\hline $\mathbf{7}$ & 75 & 25 & 2 & 3 \\
\hline $\mathbf{8}$ & 75 & 25 & 3 & 1 \\
\hline $\mathbf{9}$ & 75 & 25 & 4 & 2 \\
\hline
\end{tabular}

YRF - recycled yarn fibers.

WRF - recycled woven fibers.

\section{RESULTS AND DISCUSSION}

\section{Comparison of virgin and recycled fibers}

Recycled fiber characterization seems to be crucial to steer this material valorization. The testing of fibers was always of importance to the manufacturer who desires its exploitation. For this reason, the quality of recycled fiber will be compared to that of virgin cotton fiber.

\section{Morphological comparison}

The SEM micrographs of virgin and recycled fiber are illustrated in figure 3 . It can be seen that the virgin fiber present regular cut section (figure $3, a$ ). On the other hand, and do to repeated constraints during treatments from spinning to finishing, recycled fiber present irregular cut section (figure $3, b$ ).
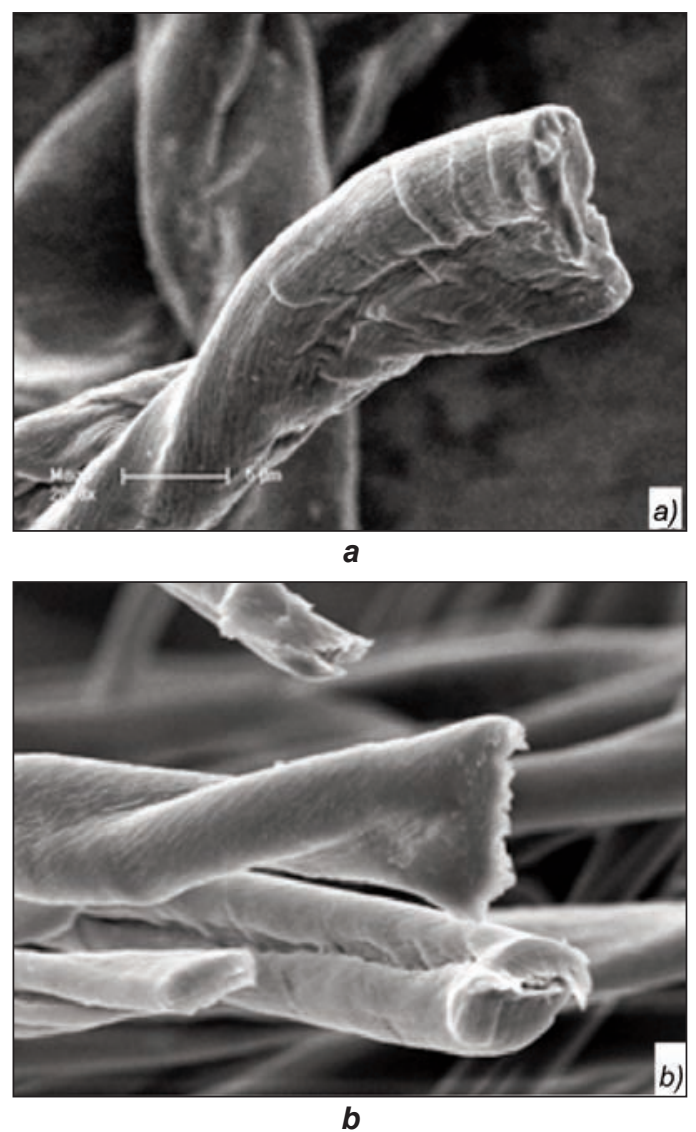

Fig. 3. SEM microographs of fracture surface of: $a$ - virgin cotton fiber, $b$ - recycled fiber

\section{Mechanical and physical comparison}

Figure 4, a presents three attributes which describe the length distribution in the cotton samples: SFC (short fiber content), L(W) (Mean length) and UQL (Upper Quarter Mean Length). It seems clear that the virgin cotton has the lowest short fiber content and longer fiber distribution. On the other side, woven recycled fibers contain the highest short fiber content and lower mean length and UQL. These results can be explained by the yarn interweaving in woven wastes which need higher mechanical constraints to be frayed. Despite these mechanical constraints in waste fraying, the mechanical properties of woven recycled fiber, elongation and strength, are slightly better than recycled yarn fiber figure $4, b$. In addition, the warp threads which run vertically through the length of the fabric, present high mechanical properties than weft threads run horizontally across the width of the cloth. It is very important to mention in this stage that this comparison does not take into account the effect of cotton origin since yarns and woven are made from the same virgin cotton blend. Contrary to the length attributes and mechanical properties; which are relatively affected by recycling process, a set of advantages come out with physical characteristics such as: neps count, micronaire and maturity figure 4, $c$ and $d$. In addition, woven and yarn recycled fibers present less neps, higher maturity and equal micronaire compared to virgin cotton (VC). These results can be explained by the fact that for yarn and woven wastes, neps and immature fibers 


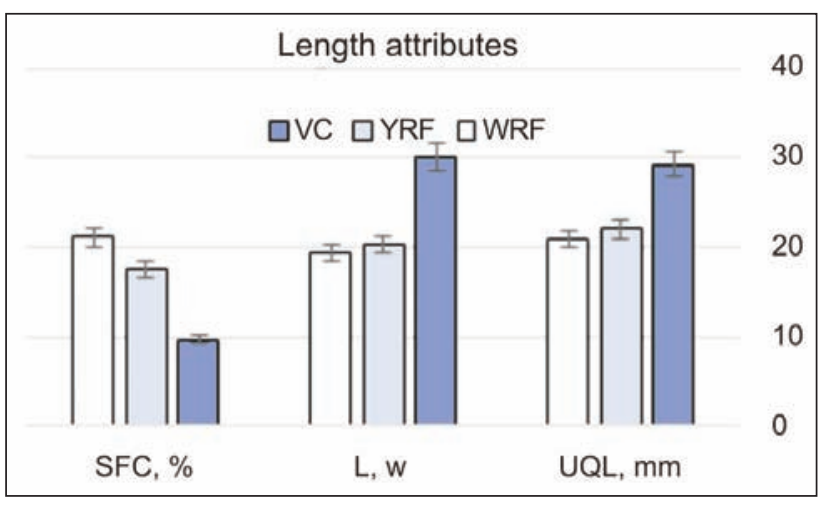

a

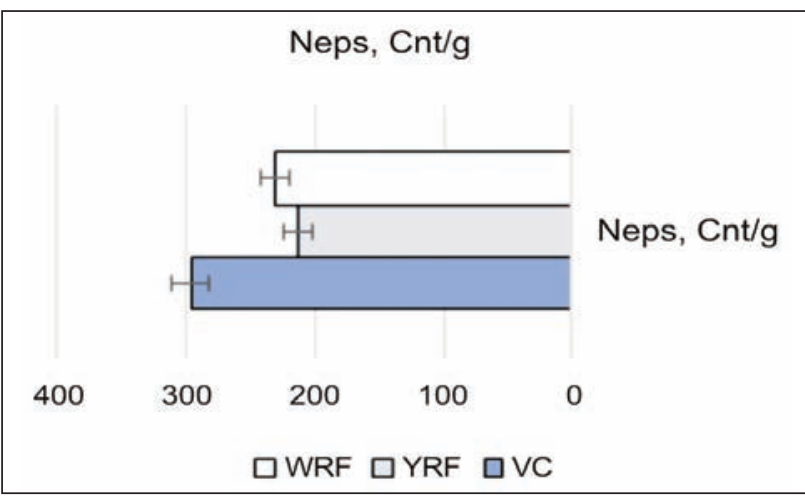

C

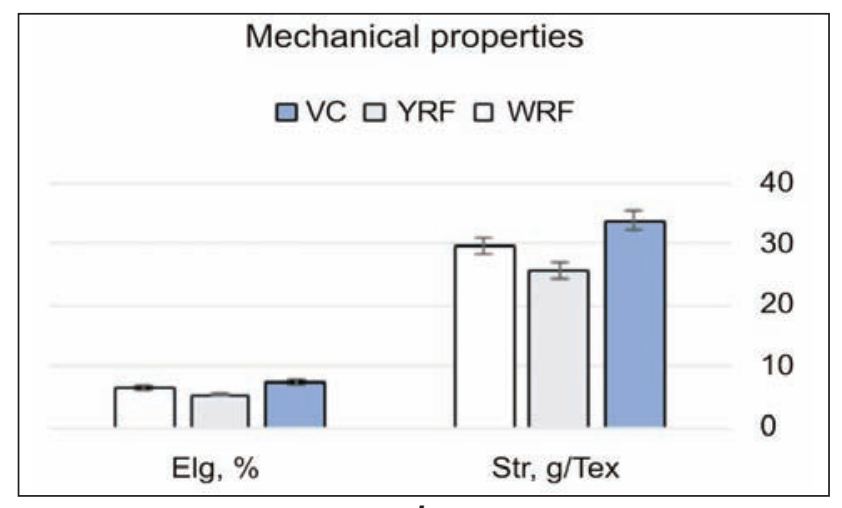

b

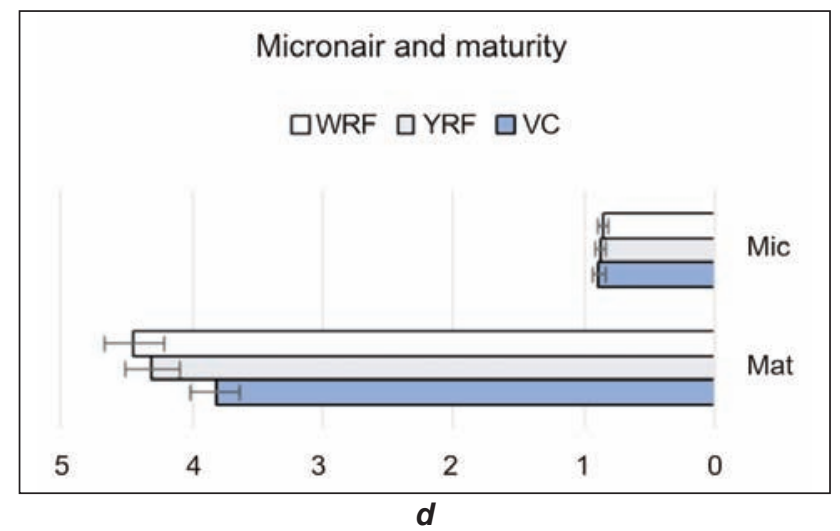

Fig. 4. $a$ - Length attributes comparaison; $b$ - Mechanical properties comparaison; $c$ - Neps count comparaison; $d$ - Micronair and maturity comparaison

are already eliminated during opening and cleaning process. Whereas, micronaire is nearly the same since we compare wastes from the same cotton origin. Current results and those from literature and technical reports [19-21], shows that these two categories of recycled fibers acquire a set of properties that enable them to be exploited in dry nonwoven manufacturing.

\section{Nonwoven quality optimization}

Nonwoven mechanical properties are very important to orientate its applications and uses. The basic aim of this part was to determine the influence of: fiber type, needle punching passage number and layer number on the area density, thickness, strength, elongation and stress.

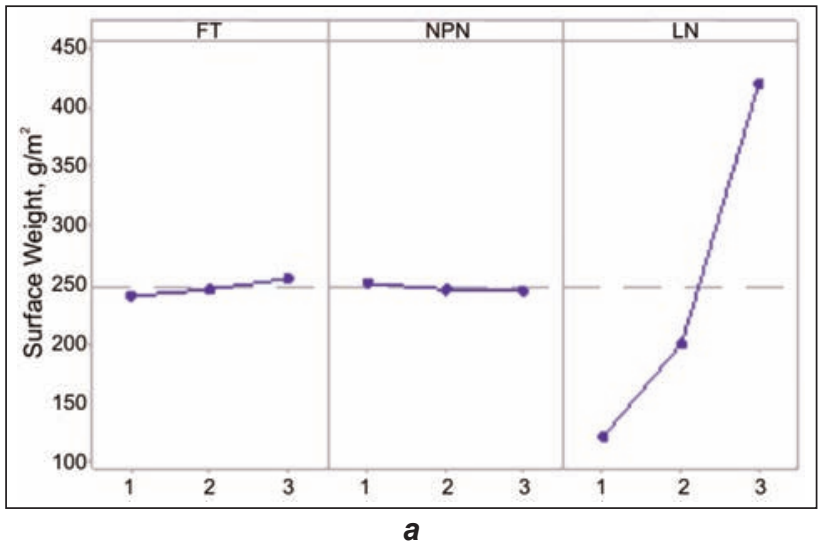

\section{Surface weight and thickness}

The main effect plot shows that the two factors FT (fiber type) and NPN (needle punching passage number) do not have a significant effect on the surface weight and the nonwoven thickness. On the other hand, the layer number (LN) has an increasing effect on the surface weight and thickness. Indeed, it is obvious that the adding of more material generates a weight and thickness rising (figure 5). It can be concluded that the initial form of recycled materials (yarn or woven) doesn't have an effect on the physical properties of obtained nonwoven.

\section{Strength and elongation}

Figure 6, a illustrates clearly that the layer number is the most influential factor on the nonwoven strength,

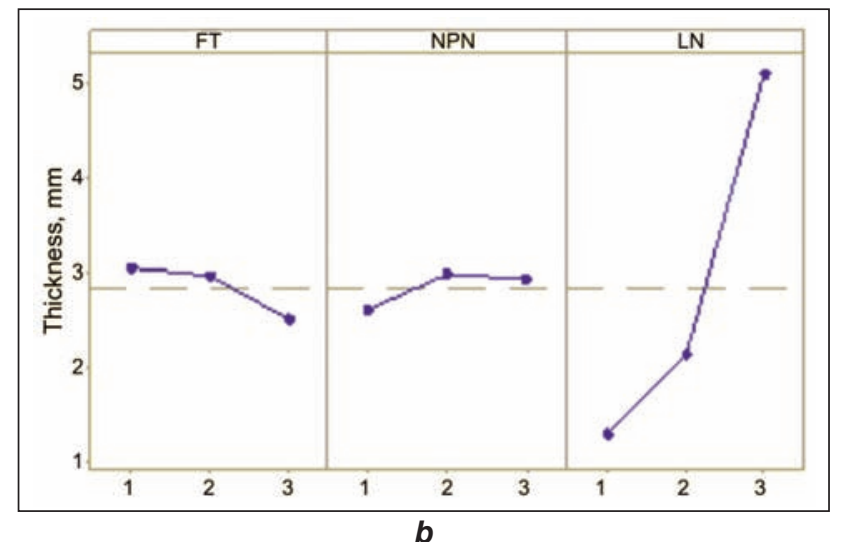

Fig. 5. $a$ - Main effect plot for nonwovensurface weight; $b$ - Main effect plot for nonwoven thickness 

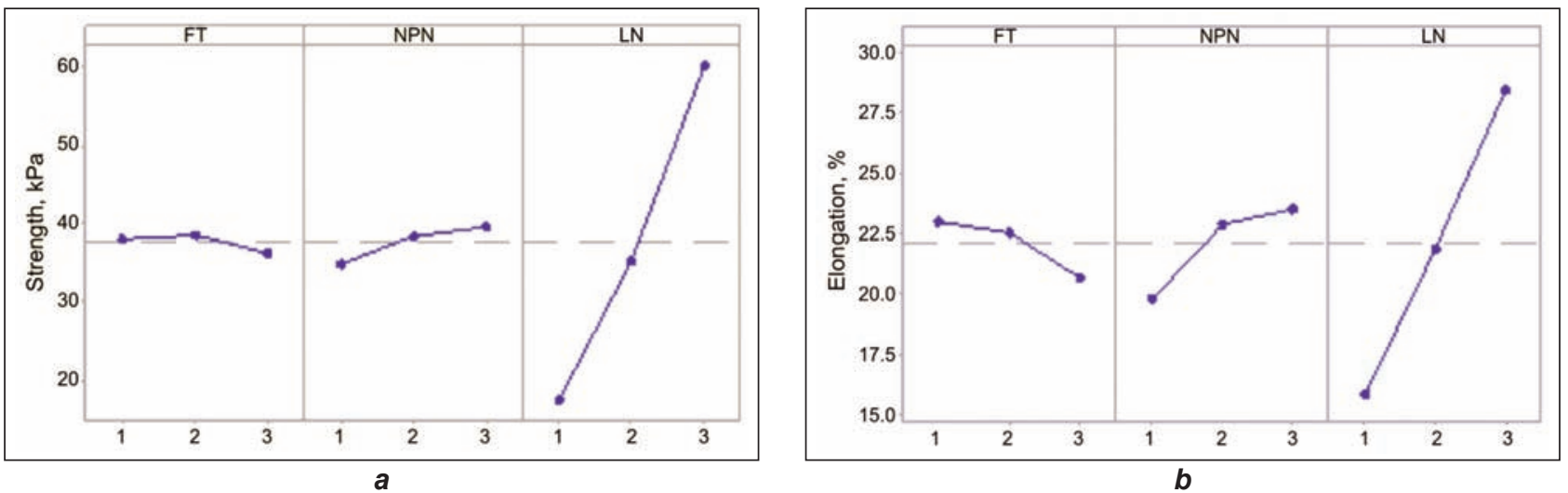

Fig. 6. $a$ - Main effect plot for nonwoven strength; $b$ - Main effect plot for nonwoven elongation

then we note the needle punching passage number whereas the effect of fiber type is, relatively limited. These results can be explained by the fact that with the increasing of layers gives more material to the structure and at the same time; the number of passage improve fibers overlapping with a deep penetration of barbed needles.

It can be seen in the main effect plot (figure $6, b$ ) that fiber type has a negative effect on nonwoven elongation. Indeed, adding woven recycled fibers reducesthe elongation property. In addition, results can be explained by the higher short fiber content in recycled woven that can be slipped inside the structure during breaking. Before being needle-punched, the web was formed with parallel fibers. But during this process, the vertical action of needles causes an entanglement between fibers which forms the web and its orientation becomes more random. Therefore, if the passage numbers of fiber web on the needle-punching machine increase, the orientation of fibers become more and more random. For this reason, during dynamometric test the rupture of the specimen was carried out only when the fibers become parallel (under the action of stretching).

Consequently, the nonwoven elongation increases when the passage number increase (fiber orientation more randomly). On the other hand, layer number and the needle punching passage numbers have an increasing effect on nonwoven elongation.

\section{CONCLUSION}

A quality assessment of recycled fibers obtained from two different kind of post-industrial wastes indicate that in spite of the repeated mechanical constraints; their physical and mechanical properties enable them to be exploited in dry nonwoven manufacturing.

According to the level average analyses, nonwoven strength, elongation is significantly affected by number of layer and needle punching passage number. Results indicate that needle punching passage number and the layer number are more influent on recycled fiber nonwoven properties then recycled fiber type.

\section{BIBLIOGRAPHY}

[1] Aminatha Kirama, Aloyce W. Mayo, Challenges and prospects of private sector participation in solid waste management in Dares Salaam City, In: Tanzania Habitat International, 2016, vol. 53, pp. 195-205.

[2] Lucia Rigamontia, Irene Sterpib, Mario Grossoa. Integrated municipal waste management systems, In: Ecological Indicators, 2016, vol. 60, pp. 1-7.

[3] Mehmet Kiziloglu, Celalettin Serinkan. Perception of strategical management in textile sector. In: Procedia - Social and Behavioral Sciences, 2015, vol. 207, pp. 306-314.

[4] Baumann H., and A.M. Tillman, The Hitch Hiker's Guide to LCA - An orientation in life cycle assessment methodology and application, In: Studentlitteratur, Lund, Sweden 2004.

[5] Beck, Almut, et al., Fate modelling within LCA - The case of Textile Chemicals, In: International Journal of LCA 5 , 2000, vol. 6, pp. 335-344.

[6] Youjiang Wang. Recycling in textiles. Georgia Institute of Technology, In: USA, eBook ISBN: 9781845691424. Woodhead Publishing, 2006.

[7] A. Bartl, A. Hackl, B. Mihalyi, M. Wistuba, I. Marini. Recycling of fiber materials, 2005, vol. 83, no. 4, pp. $351-358$.

[8] M. Taher Halimi, M. Ben Hassen, B. Azzouz and F. Sakli, Effect of cotton waste and spinning parameters on rotor yarn quality. The Textile Institute, 2007, vol. 98, no. 5, pp. 437-442.

[9] Mohamed Taher Halimi, Mohamed Ben Hassen, Faouzi Sakli, Cotton waste recycling: Quantitative and qualitative assessment. Resources, In: Conservation and Recycling. 2008, vol. 52, pp. 785-791. 
[10] Halimi Mohamed Taher, Azzouz Bechir, Ben Hassen Mohamed, Sakli Faouzi, Influence of spinning parameters and recovered fibers from cotton waste on the uniformity and hairiness of rotor spun yarn, In: Journal of Engineered Fibers and Fabrics, 2009, vol. 4, pp. 20-29.

[11] Bechir Wanassia, Bachir Azzouz, Mohamed Ben Hassen. Value-added waste cotton yarn: Optimization of recycling processand spinning of reclaimed fibers, In: Industrial Crops and Products, 2016, vol. 87, pp. 27-32.

[12] Bechir Wanassi, Bachir Azzouz, Mohamed Ben Hassen, Recycling of post-industrial cotton wastes: Quality and rotor spinning of reclaimed fibers, In: International Journal of Advanced Research.2015, vol. 3, no. 6, pp. 94-103.

[13] Hasani, H., Semnani, D., Tabatabaei, S, Determining the optimum spinning conditions to produce the rotor yarns from cotton wastes, In: Industria Textilă, vol. 61 (2010), no. 6, pp. 259-264.

[14] Shuhua Wang, Meixia Wei1, Qiaoli Xu, and Husheng Jia, Functional porous carbons from waste cotton fabrics for dyeing wastewater purification, In: Fibers and Polymers 2016, vol.17, no. 2, pp. 212-219.

[15] Alomayri T., Shaikh F.U.A., Low I.M. Effect of fabric orientation on mechanical properties of cotton fabric reinforced geopolymer composites, In: Mater Design 2014, vol. 57, pp. 360-365.

[16] S. Sakthivel, T. Ramachandran, G. Archana, Ezhilanban J.J, V.M.S. Sivajith Kumar. Sustainable non wovenfabric composites for automotive textiles using reclaimed FIBERS, In: International Journal of Engineering Research and Development, 2012, vol. 4, no. 7, pp. 11-13.

[17] Arun Kumar Gupta, Manoranjan Biswal, S. Mohanty, and S. K. Nayak*, Mechanical and thermal degradation behavior of sisal fiber (SF) reinforced recycled polypropylene (RPP) composites. In: Fibers and Polymers 2014, vol. 15, pp. 994-1003.

[18] Natascha M. van der Velden, Kristi Kuusk, Andreas R. Köhler. Life cycle assessment and eco-design of smart textiles: The importance of material selection demonstrated through e-textile product redesign, In: Materials \& Design, 2015, vol. 84, pp. 313-316.

[19] Nicholas Morley, OHL Stephen Slater, OHL Stephen Russell, NIRI Matthew Tipper, NIRI Garth D Ward, SATCoL. Recycling of low grade clothing waste, In: Technical report: DEFR01 058 Low Grade Clothing - Public v2. 30th September 2006.

[20] Chen, Y., Chiparus, O., Sun, L., Negulescu, I., Parikh, D.V. and Calamari, T.A. Natural fibers for automotive nonwoven composites. In: Journal of Industrial Textiles, 2005, vol. 35, pp. 47-62.

[21] Meng, J., Song, L. and Meng, J. Using single-walled carbon nanotubes nonwoven films as scaffolds to enhance long-term cell proliferation. In: Journal of Biomedical Materials Research Part A. 2006, vol. 79A, pp. 298-306.

\section{Authors:}

\section{MOHAMED TAHER HALIMI ${ }^{1}$, MOHAMED BEN HASSEN ${ }^{2,3}$, BECHIR WANNASSI $^{3}$}

${ }^{1}$ Financial and Administrative Sciences Department, Community College Dammam, Imam Abdulrahman Bin Faisal University, P.O. Box 1982 Dammam, Kingdom of Saudi Arabia e-mail: mthalimi@iau.edu.sa

2Department of Industrial Engineering, College of Engineer, Taibah University, Madina, Saudi Arabia e-mail: m.benhassen@taihbahu.edu.sa, benrayen@yahoo.fr

${ }^{3}$ Laboratory of Textile Engineering, University of Monastir, ISET Ksar Hellal, Tunisia

\section{Corresponding author:}

MOHAMED BEN HASSEN

e-mail: m.benhassen@taihbahu.edu.sa, benrayen@yahoo.fr 